\title{
CHEMICAL COMPOSITION OF ESSENTIAL OILS AND ITS LOCOMOTOR ACTIVITY FROM THE BARKS OF CINNAMOMUM SINTOC BL. OF TWO DISTRICTS IN MIDDLE JAVA
}

\author{
MUCHTARIDI MUCHTARIDI ${ }^{1 *}$, SRI A SUMIWI ${ }^{2}$, RINA F NUWARDA ${ }^{1}$
}

${ }^{1}$ Department of Pharmaceutical Analysis and Medicinal Chemistry, Faculty of Pharmacy, Padjadjaran University, Jatinangor, Bandung Sumedang, West Java, Indonesia. ${ }^{2}$ Department of Pharmacology and Clinical Pharmacy, Faculty of Pharmacy, Padjadjaran University, Jatinangor, Bandung Sumedang, West Java, Indonesia. Email: muchtaridi@unpad.ac.id

Received: 20 October 2016, Revised and Accepted: 31 January 2017

ABSTRACT

Objective: The objective of this study was to determine of volatile compounds of essential oils from Cinnamomum sintoc Bl (Sintok) barks belongs to Lauraceae of two districts of Middle Java.

Methods: Analysis of essential oil components from the barks of $C$. sintoc $\mathrm{Bl}$ was performed by confirmation of the linear retention indices, following by the comparison of NIST library peak and mass spectrum peak with literature data.

Results: The essential oils from Yogyakarta and Jember of $C$. sintoc $\mathrm{Bl}$ obtained by steam distillation with the percentage of $1.10 \%$ and $1.15 \%$ (w/w), respectively, with eugenol and methyl eugenol having higher percentage, compare to other components, $35-38 \%$ and $<10 \%$, respectively. The sintok barks oil of Yogyakarta at $0.1 \mathrm{~mL}$ a dose decreased the locomotor activity as much as $11.33 \%$, while at 0.3 and $0.5 \mathrm{~mL}$ doses increased the locomotor activity as much as $35.83 \%$ and $51.13 \%$.

Conclusion: It can be concluded from this study that the inhalation of sintok barks oil gave different influence to locomotor activity depends on the doses given.

Keywords: Cinnamomum sintoc $\mathrm{Bl}$, Methyl eugeunol, Linear retention indices, Eugenol.

(C) 2017 The Authors. Published by Innovare Academic Sciences Pvt Ltd. This is an open access article under the CC BY license (http://creativecommons. org/licenses/by/4. 0/) DOI: http://dx.doi.org/10.22159/ajpcr.2017.v10i4.15780

\section{INTRODUCTION}

Some fragrance components of aromatic plants used for cooking are known to influence locomotor activity [1]. The first study on aromatherapy was performed by Kovar and coworker who investigated the effect of inhalation of essential oil toward the motor behavior of mice. Kovar and coworker were intended to prove the benefit of essential oil and its single component which administered by inhalation. Essential oils from rosemary and dwarf pines have been proven to increase the motoric activity, while those from Melissa and Valerian showed the opposite effects [2,3]. Muchtaridi et al. investigated that some essential oils of Indonesian aromatic plants inhibit the locomotor activity of mice $[1,4]$. Sintok is an aromatic plant that grows in Indonesia, Malaysia, and Thailand with a woody stem extending involved in Lauraceae tribe.

Empirically, sintok is utilized as outer or inner medicines. It is used to treat worms in the belly, amoebic dysentery, and swelling (inflammation). Sintoc bark (Cinnamomum sintoc $\mathrm{Bl}$ ) belongs to Lauraceae family. It has been used as common treatment for swelling caused by insects' bites [5].

Research on chemical contents of sintoc bark has been conducted not only in Indonesia but also other countries. Jantan et al. examined chemical contents in sintoc bark form Malayan peninsula using gas chromatography and mass spectroscopy [6]. They found that sintoc barks consist of safrole (23.4\%), murolen (13.5\%), along with adequate amounts of eugenol, linalool, germakren, kadinen, terpinol, and the other terpenes.

Currently, the study to determine anti-inflammation activity from ethanol extract and the fraction solvent of sintok barks has been carried out. However, further research in finding an active compound of sintok still needs to be done [7]. Research on the activity of essential oil of sintoc bark from Malaysia showed that the essential oil has an in vitro anti-inflammatory activity by antagonizing lipoxygenases and platelet activating factor while in vivo it inhibits edema in mice's ear induced by tetradecanoylphorbol acetate [8]. However, the locomotor activity of essential oils of $C$. sintoc Bl (Sintok) barks has been yet reported. Therefore, the aim of this study was to examine the effect of essential oils from sintok barks on locomotor activity of mice.

\section{MATERIALS AND METHODS}

\section{Materials}

Plant materials

C. sintoc Bl plants were collected in July 2005 from Yogyakarta and Jember of Central Java. Specimens were identified by the Herbarium Laboratory, Department of Biology, Faculty of Mathematics and Natural Sciences, Universitas Padjadjaran and then stored in the Herbarium Biology Department, Faculty of Mathematics and Natural Sciences, Universitas Padjadjaran. $5 \mathrm{~kg}$ of sintok barks were dried in the open air for 14 days at room temperature then weighed $1 \mathrm{~kg}$ each for distillation.

\section{Animals}

Male mice weighing 25-30 g with age 2-3 months old were used. The mice were adapted for 1 week to the laboratory condition in which locomotor activity experiments were conducted and were selected for wheel rotations between 150 and $300 \mathrm{rpm}$ before the experiments were started.

\section{Methods}

Isolation of essential oil

All dry samples (1 kg) were distilled using steam-distillation in Monaco Lembang, West Java, for $3 \mathrm{hrs}$ to isolate the essential oil fraction. Oil stored at $-20^{\circ} \mathrm{C}$ after the addition of sodium sulfate. 


\section{Analytical condition}

Essential oils were analyzed based on a previous study [9]. The identification of compounds was conducted by screening a digital library of mass spectral data with a Class-5000 software and by comparison of retention indices and mass spectra library authentic (NIST and WILLEY) [10-13], relative to the C8-C20 and C21-C40 n-alkane series (Sigma) [14] in a temperature-programmed run.

\section{Mouse locomotor activity tests}

Locomotor activity was measured by recording the number of rotations of mice while running in a wheel cage using a meter. The locomotor evaluation condition methods refer to our previous study [1,15]. All experimental procedures for animal use have been approved by the Ethical Committee of Experimental Animals, Universitas Padjadjaran.

\section{RESULTS AND DISCUSSION}

\section{Chemical composition of essential oils}

Sintok barks oils from Yogyakarta and Jember contained $1.10 \%$ and $1.15 \%(\mathrm{w} / \mathrm{w})$ of essential oils, respectively. Bark oil originated from Yogyakarta produced eugenol as the major component (38.38\%) followed by myristicin $(13.54 \%)$, safrole $(10.17 \%)$, benzyl benzoat (4,66\%), $\alpha$-terpineol (4.40\%), 4-terpineol (4.26\%), methyl eugenol (4.14\%), $\Delta$-cadinol $(1.28 \%)$, and isomyristicin (1.14\%) (Table 1). The other components which were produced $<1 \%$ were $\alpha$-cadinol, $\Delta$-cadinene, isopulegol, junifer camfphore, $\alpha$-curcumene, borneol, L-linalool, $\alpha$-copaene, camphore, bornyl acetate, $\alpha$-calocorene, 1,8-cineol, tymol, gernacrene, caryophyllene oxide, globulol,

Table 1: Constituents of bark essential oil from sintok from Jogyakarta

\begin{tabular}{lllll}
\hline S.No. & LRI $^{\mathbf{1}}$ & LRI $^{\mathbf{2}}$ & Compounds name & Percentage (\%) \\
\hline 1 & 1028 & 1031 & L-Limonene & 0.08 \\
2 & 1033 & 1039 & 1,8-cineol & 0.27 \\
3 & 1095 & 1098 & L-linalool & 0.47 \\
4 & 1140 & 1146 & Isopulegol & 0.72 \\
5 & 1146 & 1143 & Camphor & 0.41 \\
6 & 1162 & 1165 & Borneol & 0.48 \\
7 & 1174 & 1177 & 4-terpineol & 4.26 \\
8 & 1191 & 1189 & $\alpha$-terpineol & 4.40 \\
9 & 1275 & 1285 & Bornyl acetate & 0.31 \\
10 & 1287 & 1285 & Safrol & 10.17 \\
11 & 1291 & 1290 & Timol & 0.25 \\
12 & 1358 & 1356 & Eugenol & 38.38 \\
13 & 1372 & 1376 & $\alpha$-copaene & 0.47 \\
14 & 1400 & 1401 & Metylceugenol & 4.14 \\
15 & 1412 & 1408 & Trans-caryophyllen & 0.06 \\
16 & 1420 & 1418 & $\beta$-caryophyllen & 0.06 \\
17 & 1428 & 1439 & Aromadendrene & 0.17 \\
18 & 1444 & 1477 & $\gamma$-murolene & 0.17 \\
19 & 1450 & 1483 & $\alpha$-curcumene & 0.50 \\
20 & 1486 & 1499 & $\alpha$-murolene & 0.16 \\
21 & 1508 & 1503 & Gernacrene & 0.22 \\
22 & 1518 & 1524 & $\Delta$-cadinene & 0.78 \\
23 & 1520 & 1520 & Myristicin & 13.54 \\
24 & 1540 & 1542 & $\alpha$-calocorene & 0.28 \\
25 & 1575 & 1576 & Spatulenol & 0.07 \\
26 & 1582 & 1581 & Caryophyllene oxide & 0.20 \\
27 & 1587 & 1583 & Globulol & 0.20 \\
28 & 1591 & 1590 & Viridiflorol & 0.14 \\
29 & 1620 & - & Isomyristicin & 1.14 \\
30 & 1638 & 1640 & $\Delta$-cadinol & 1.63 \\
31 & 1648 & 1653 & $\alpha$-cadinol & 0.98 \\
32 & 1665 & 1691 & Junifer camphor & 0.69 \\
33 & 1700 & - & Eugenic acid & 0.24 \\
34 & 1760 & 1762 & Benzyl benzoate & 4.66 \\
35 & 1857 & - & Eugenol derivative & 0.28 \\
36 & 2176 & - & Hexadecanoic acid & 1.00 \\
\hline
\end{tabular}

${ }^{1}$ LRI experiment with DB5-MS column, ${ }^{2}$ LRI Adams [13] with DB5 column. LRI: Linear retention indices aromadendrene, $\gamma$-murolene, $\alpha$-murolene, viridiflorol, L-limonene, spatulenol, t-caryophyllene, and $\beta$-caryophyllene.

Eugenol was still a major component with $26.31 \%$ in sintok oil from Jember, followed by 35 other compounds. Yields of eugenol and methyl eugenol in sintok barks Yogyakarta oil more than the sintok barks Jember oil, while myristicin was presented in a similar level as shown in Table 2 .

However, $\alpha$-terpineol (5.64\%) and 4-terpineol (5.67\%) of sintok barks Jember oil had a higher percentage than sintok barks Yogyakarta oil. Eugenol derivatives were produced more in sintok barks Jember oil than sintok barks Yogyakarta oil. Eugenol and methyl eugenol were also found in cloves, basil, and nutmeg. Eugenol and ethyl eugenol are used commonly for medicine and agriculture.

Eugenol and methyl eugenol are found as the most active attractant for the oriental fruit fly, Bactrocera dorsalis [16]. As medicine, these compounds reduce pain and inflammation for dental treatment $[17,18]$ and muscle arthritis.

The composition of barks sintok oil in this study were significantly different from those reported by Jantan et al. [6], which indicated that the linalool was dominant in barks oil (23.8\%), followed tetradecanal (16\%). Surprisingly, eugenol and their derivatives did not found in bark of sintok Pahang, Malaysia. Jantan et al. reported that the most abundant component of the bark oil was linalool (23.8\%). Except for

Table 2: Constituents of bark essential oil from sintok from Jember

\begin{tabular}{lllll}
\hline S.No. & LRI $^{\mathbf{1}}$ & LRI $^{\mathbf{2}}$ & Compounds name & Percentage (\%) \\
\hline 1 & 1100 & 1098 & L-linalool & 0.89 \\
2 & 1107 & 1097 & t-sabinen hidrat & 0.11 \\
3 & 1140 & 1143 & Camphor & 0.25 \\
4 & 1160 & 1165 & Borneol & 0.78 \\
5 & 1174 & 1177 & 4-terpineol & 5.64 \\
6 & 1181 & 1189 & $\alpha$-terpineol & 5.71 \\
7 & 1280 & 1285 & Bornil asetat & 0.27 \\
8 & 1285 & 1285 & Safrol & 7.62 \\
9 & 1288 & 1290 & Timol & 0.05 \\
10 & 1350 & 1356 & Eugennol & 26.31 \\
11 & 1370 & 1376 & $\alpha$-copaene & 0.90 \\
12 & 1402 & 1401 & Methyl eugeunol & 2.35 \\
13 & 1406 & 1402 & Isoeugenol & 1.07 \\
14 & 1410 & 1408 & Trans-caryophyllen & 0.69 \\
15 & 1412 & 1418 & $\beta$-caryophyllen & 0.66 \\
16 & 1427 & 1439 & Aromadendrene & 0.56 \\
17 & 1444 & 1477 & $\gamma$-murolene & 0.51 \\
18 & 1445 & 1483 & $\alpha$-curcumene & 0.89 \\
19 & 1487 & 1499 & $\alpha$-murolene & 1.38 \\
20 & 1503 & 1503 & Gernacrene & 0.70 \\
21 & 1517 & 1524 & $\Delta$-cadinene & 2.37 \\
22 & 1518 & 1520 & Myristicin & 13.00 \\
23 & 1592 & 1542 & $\alpha$-calocorena & 0.94 \\
24 & 1570 & 1576 & Spatulenol & 1.96 \\
25 & 1575 & 1581 & Kariofilen oksida & 0.58 \\
26 & 1580 & 1583 & Globulol & 0.50 \\
27 & 1601 & 1590 & Viridiflorol & 1.47 \\
28 & 1610 & - & Isomyristicin & 0.58 \\
29 & 1622 & 1640 & $\Delta$-cadinol & 1.68 \\
30 & 1638 & 1653 & $\alpha$-cadinol & 1.27 \\
31 & 1676 & 1691 & Junifer camphor & 2.16 \\
32 & 1680 & - & Eugeunic acid & 0.89 \\
33 & 1698 & & Methyl & 0.60 \\
34 & 1762 & 1762 & Benzyl benzoat & 0.75 \\
35 & 1857 & & Eugenol derivate & 3.95 \\
36 & 2176 & & Hexadecanoic acid & 0.32 \\
\hline
\end{tabular}

${ }^{1}$ LRI experiment with DB5-MS column, ${ }^{2}$ LRI Adams [13] with DB5 column. LRI: Linear retention indices 
Table 3: Average number of mice wheel cage rotations within 75 minutes of inhalation of rhizome and leaf essential oils from $C$. sintok oil

\begin{tabular}{|c|c|c|c|c|c|c|c|}
\hline \multirow[t]{3}{*}{ Treatments } & \multicolumn{6}{|c|}{ Mean instead of number of average } & \multirow[t]{3}{*}{$\%$ Inhibitory effect } \\
\hline & \multicolumn{6}{|l|}{ Minutes } & \\
\hline & $0-15$ & $15-30$ & $30-45$ & $45-60$ & $60-75$ & Total of average & \\
\hline \multicolumn{8}{|l|}{ Controls } \\
\hline 0 & $313.6 \pm 21$ & $298.3 \pm 11$ & $300.2 \pm 30$ & $290.2 \pm 15$ & $278.3 \pm 11$ & 1480.6 & 0 \\
\hline \multicolumn{8}{|l|}{ Lavender oils } \\
\hline 0.1 & $144.2 \pm 33$ & $142.2 \pm 31$ & $142.3 \pm 12$ & $135.9 \pm 19$ & $131.3 \pm 18$ & 695.9 & $52.994^{*}$ \\
\hline 0.3 & $120.7 \pm 20$ & $121.2 \pm 28$ & $112.8 \pm 31$ & $110.9 \pm 24$ & $109.2 \pm 26$ & 574.8 & $61.18^{*}$ \\
\hline 0.5 & $115.6 \pm 25$ & $114.8 \pm 30$ & $116.8 \pm 41$ & $100.2 \pm 11$ & $90.2 \pm 11$ & 537.6 & $63.69^{* * *}$ \\
\hline \multicolumn{8}{|c|}{ Laja gowah leaf oil } \\
\hline 0.1 & $268.9 \pm 22$ & $263.2 \pm 23$ & $268.9 \pm 41$ & $258.9 \pm 34$ & $245.2 \pm 10$ & 1305.1 & $11.85^{*}$ \\
\hline 0.3 & $216 \pm 42$ & $210.3 \pm 22$ & $205.5 \pm 30$ & $200.5 \pm 22$ & $199.9 \pm 19$ & 1032.2 & $30.28 * *$ \\
\hline 0.5 & $140.3 \pm 06$ & $135.3 \pm 15$ & $131.1 \pm 08$ & $124 \pm 23$ & $125.5 \pm 17$ & 656.2 & $50.68^{*}$ \\
\hline \multicolumn{8}{|c|}{ Laja gowah stem oil } \\
\hline 0.1 & $288.9 \pm 41$ & $266.5 \pm 11$ & $262.9 \pm 09$ & $260.9 \pm 26$ & $250.1 \pm 26$ & 1329.3 & $10.22 *$ \\
\hline 0.3 & $236.5 \pm 08$ & $230.2 \pm 13$ & $210.1 \pm 25$ & $210.5 \pm 28$ & $201.4 \pm 22$ & 1088.7 & $22.45^{* *}$ \\
\hline 0.5 & $148.2 \pm 18$ & $150.2 \pm 08$ & $140.4 \pm 22$ & $130.5 \pm 33$ & $127.6 \pm 27$ & 696.9 & $52.93 *$ \\
\hline
\end{tabular}

${ }^{*} \mathrm{~F}_{6,35}=3.30 ; \mathrm{p}<0.05$, as compared with the control treatment (by ANOVA followed by Duncan post hoc test). ${ }^{*} \mathrm{~F}_{6.35}=14.10$; $\mathrm{p}<0.01$, as compared with the control treatment (by ANOVA followed by Duncan post hoc test). ${ }^{* * *} \mathrm{~F}_{6,35}=26.10 ; \mathrm{p}<0.001$, as compared with the control treatment (by ANOVA followed by Duncan post hoc test).

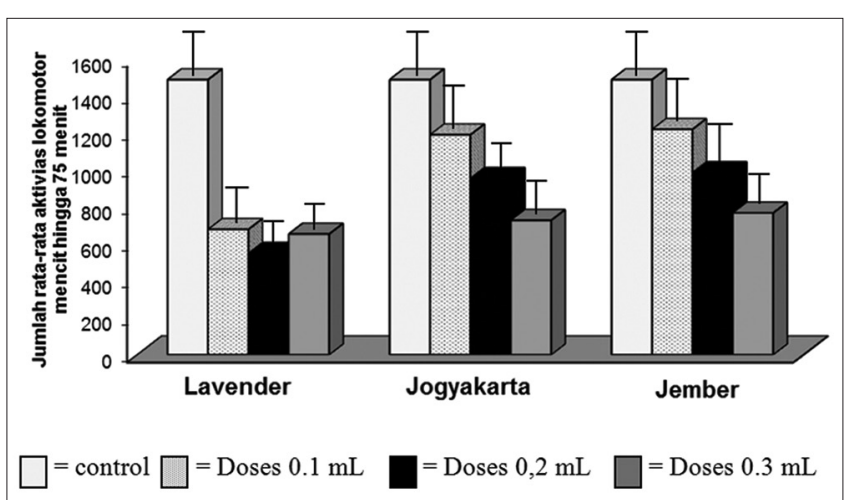

Fig. 1: Bar group of the average numbers of locomotors of mice after inhalation of essential oils within 75 minutes

terpinen-4-ol (2.4\%) and p-cymene (1.3\%), the other monoterpenes were present in $<1 \%$ concentration in the oil [6].

This study was carried out using steam distillation for $3 \mathrm{hrs}$. The method was different from Jantan et al. who was using distilled water (or water distillation?) for $8 \mathrm{hrs}$. These differences might affect the yields of the components obtained. In addition, geographic and seasonal factors may also be important aspects in determining the chemical compositions [15].

Locomotors activity inhibition of bark oil from sintok (C. sintoc Bl) The effect of the bark essential oils from sintok on locomotors activity in mice was evaluated. As shown in Table 3, in general, the two sintok bark essential oils have a significant locomotor inhibitory activity compared to positive control (lavender oil). Locomotors activity of lavender oil as positive control showed higher inhibition than sintok bark oil. The inhibition locomotors activity of sintok bark oil from Yogyakarta higher than sintok bark oil from Jember as shown in Fig. 1.

Inhalation of sintok barks essential oil decreased mice locomotor activity in a dose-dependent manner. The essential oils of sintok bark at doses of $0.1,0.3$, and $0.5 \mathrm{~mL}$ decreased locomotor activity by $11.85 \%$, $30.28 \%$, and $50.68 \%$, respectively, and those of Jember sintok oils at the same doses caused a locomotor activity decrease of $10.22 \%, 22.45 \%$, and $52.93 \%$, respectively. These dose-dependent effects might be due to higher concentrations of active components in the higher doses. On the other hand, the sintok bark oils showed strong but not dose-dependent inhibitory effects, in that the dose of $0.3 \mathrm{~mL}$ had a lower effect than that of 0.1 and $0.5 \mathrm{~mL}$.

\section{FURTHER DISCUSSION}

In Indonesia, $C$. sintoc $\mathrm{Bl}$ is not cultivated and does not receive serious attention by the government. We recommend that this plant is given special attention as it has been proved that all the major components in the essential oils of this plant has been used as a fragrance ingredient and thus, has a good prospect in the future. In Central and West Java, sintok barks have still been purchased in the market whereas the plantation is very rare. Some Herbal Industries also use this plant for Jammu products.

Methyl eugenol can be found in fragrances and has been used extensively as a flavoring agent in many types of processed food, soft drinks, and sauces, perfumery, as an essential oil in aromatherapy, and cosmetics [19]. This compound has been used as an entomological perspective [20].

Eugenol exhibits pharmacological effects in almost all systems, such as penetration enhancer. It is and a very promising candidate for versatile applications, and the design of new drugs based on its pharmacological effects. $\alpha$-terpineol, 4-terpineol, linalool, and 1.8-cineol are used as fragrance ingredients that have the smell of fresh and are used in large quantities in the aroma and taste [21,22].

The inhibition of locomotor activity by sintok barks oil from both Yogyakarta and Jember should be further investigated due to the toxic components which they contained (myristicin, safrole, and isomyristicin). In addition, eugenol and their derivatives can be considered as massage oils due to its effect to reduce acute pain.

\section{ACKNOWLEDGMENT}

We gratefully acknowledge the Rector of Universities Padjadjaran and the Indonesian Ministry of National Education for funding this work through the DIPA 2005 research grant. We also would like to thanks to Dr. Clara Sunardi, MS for her contribution to this project.

\section{REFERENCES}

1. Muchtaridi M, Diantini A, Subarnas A. Analysis of Indonesian spice essential oil compounds that inhibit locomotor activity in mice. Pharmaceuticals 2011;4(4):590-602.

2. Kovar KA, Gropper B, Friess D, Ammon HP. Blood levels of 1,8-cineole and locomotor activity of mice after inhalation and oral administration of rosemary oil. Planta Med 1987;53(4):315-8.

3. Buchbauer G, Jirovetz L, Jäger W, Dietrich H, Plank C. Aromatherapy: Evidence for sedative effects of the essential oil of lavender after inhalation. Z Naturforsch C 1991;46(11-12):1067-72.

4. Muchtaridi M, Tjiraresmi A, Febriyanti R. Analysis of active compounds 
in blood plasma of mice after inhalation of cajuput essential oil (Melaleuca leucadendron L.). Indonesian J Pharm 2015;26(4):219-27.

5. Wiart C. Ethnopharmacology of Medicinal Plants Asia and the Pacific. Totowa, New Jersey: Humana Press: 2006

6. Jantan IB, Yalvema MF, Ayop N, Ahmad AS. Constituents of the essential oils of Cinnamomum sintoc Blume from a mountain forest of Peninsular Malaysia. Flavour Frag J 2005;20(6):601-4.

7. Sumiwi SA, Subarnas A, Supriyatna S, Abdasah M, Muchtaridi M. Analysis of chemical composition and its analgesic and antiinflammatory activity of essential oil of sintoc bark (Cinnamomum sintoc bl.) using in vivo methods. J Appl Pharm Sci 2015;5(2):58-65.

8. Jantan I, Rafi IA, Jalil J. Platelet-activating factor (PAF) receptor-binding antagonist activity of Malaysian medicinal plants. Phytomedicine 2005;12(1-2):88-92.

9. Muchtaridi M, Musfiroh I. Off-line SPE-GC/MS analysis of lead compounds aromatherapy in blood plasma of mice of essential oils materials from Indonesian aromatic plants. Asian J Chem 2012;24:5124.

10. Strehmel N, Hummel J, Erban A, Strassburg K, Kopka J. Retention index thresholds for compound matching in GC-MS metabolite profiling. J Chromatogr B Analyt Technol Biomed Life Sci 2008;871(2):182-90.

11. Ausloos P, Clifton CL, Lias SG, Mikaya AI, Stein SE, Tchekhovskoi DV, et al. The critical evaluation of a comprehensive mass spectral library. J Am Soc Mass Spectrom 1999;10(4):287-99.

12. Babushok VI, Linstrom PJ, Reed JJ, Zenkevich IG, Brown RL, Mallard WG, et al. Development of a database of gas chromatographic retention properties of organic compounds. J Chromatogr A 2007;1157(1-2):414-21.

13. Adams RP. Identification of Essential Oil Components by Gas Chromatography - Mass Spectroscopy. Illinois: Allured Publishing Corporation; 1995.
14. Mijin DZ, Petrovic SD, Antonovic DG. Gas chromatography retention indices of 2-phenyl-2 alkylacetonitriles on packed coloumns. Sci J Facta Univ 1999;2(1):1-8.

15. Muchtaridi M, Musfiroh I, Subarnas A, Rambia I, Suganda H, Nasrudin ME. Chemical composition and locomotors activity of essential oils from the rhizome, stem, and leaf of Alpinia malaccencis (Burm F.) of Indonesian spices. J Appl Pharm Sci 2014;4:52.

16. Metcalf RL, Mitchell WC, Fukuto TR, Metcalf ER. Attraction of the oriental fruit fly, Dacus dorsalis, to methyl eugenol and related olfactory stimulants. Proc Natl Acad Sci U S A 1975;72(7):2501-5.

17. Dal Bó W, Luiz AP, Martins DF, Mazzardo-Martins L, Santos AR. Eugenol reduces acute pain in mice by modulating the glutamatergic and tumor necrosis factor alpha (TNF-a) pathways. Fundam Clin Pharmacol 2013;27(2):517-25.

18. Koh T, Murakami Y, Tanaka S, Machino M, Sakagami H. Re-evaluation of anti-inflammatory potential of eugenol in IL-1ß-stimulated gingival fibroblast and pulp cells. In Vivo 2013;27:269-73.

19. Tan KH, Nishida R. Methyl eugenol: Its occurrence, distribution, and role in nature, especially in relation to insect behavior and pollination. J Insect Sci 2012;12:56.

20. Vargas RI, Shelly TE, Leblanc L, Piñero JC. Recent advances in methyl eugenol and cue-lure technologies for fruit fly detection, monitoring, and control in Hawaii. Vitam Horm 2010;83:575-95.

21. Zitzelsberger C, Buchbauer G. Essential oils as "A cry for help". A review. Nat Prod Commun 2015;10(6):1127-38.

22. Buchbauer G, Jäger W, Jirovetz L, Meyer F, Dietrich H. Effects of valerian root oil, borneol, isoborneol, bornyl acetate and isobornyl acetate on the motility of laboratory animals (mice) after inhalation. Pharmazie 1992;47(8):620-2 